\title{
UNCERTAINTY IN MINIMUM INSTREAM FLOW REQUIREMENTS FOR STREAMS IN SEMI-ARID ENVIRONMENTS
}

\author{
MICHAEL BARBER ${ }^{1} \&$ ROBERT MAHLER ${ }^{2}$ \\ ${ }^{1}$ Civil and Environmental Engineering, University of Utah, USA \\ ${ }^{2}$ Soil Science Division, University of Idaho, Moscow, ID, USA
}

\begin{abstract}
ABSRACT
Increased competition for water resources in arid and semi-arid watersheds is prompting management agencies to adopt instream flow requirements for critical aquatic habitats. For instance, because of increasing concerns for bull trout and salmonid species in the Touchet River system, minimum instream flows are needed to protect several important rearing and spawning reaches. The study included a field reconnaissance of the region with specific emphasis on known migration blockages, spawning and rearing habitat areas, and other areas identified in the project scoping meeting. Eight representative cross sections were selected at each of seven stream segments based on this initial field reconnaissance survey. Care was taken to include pool, spawning, riffle and other unique stream characteristics. Depth and velocity profiles were measured at each of the cross sections at three different water stages: high, medium and low. Substrate grab samples were taken along each of the eight reaches for subsequent analysis. Temperature data along with several other basic water quality parameters (i.e. dissolved oxygen, $\mathrm{pH}$, conductivity and turbidity) and an assessment of vegetative cover were also recorded during sampling. Minimum instream flow modelling and analysis were conducted using the instream flow incremental methodology technique. Habitat suitability indices were assigned to each stream cell. Non-binding recommendations for instream flow values were provided to management agencies. A considerable amount of uncertainty exists in the preference factors assigned to the various life stages of bull trout and salmonid species. Much of this stems from the processes traditionally used to determine factors related to juvenile rearing, spawning and migration. A conclusion of this study was that preference curves developed for wet regions were not applicable to semi-arid river basins where stream flows are often quite small in comparison. This study documents the assumptions, procedures and results of this investigation and demonstrates the potential impacts of uncertainty on the results.

Keywords: aquatic habitat, ecological protection, environmental flows, IFIM
\end{abstract}

\section{INTRODUCTION}

Over-appropriation of water in many river basins throughout the world is increasingly causing shortages of domestic, industrial, agricultural and environmental supplies [1]. It has been estimated that 1.4 billion people live in areas where water demand is greater than the supply during at least part of the year [2]. In the semi-arid western United States, where the prior appropriation doctrine governs water allocation through water right systems based on first in time priority, increased competition for water resources for population growth and climate change adaptation is prompting management agencies to adopt instream flow requirements for protection of critical aquatic habitats. The three most commonly used methods for establishing these flow requirements are the (1) Instream Flow Incremental Methodology (IFIM), (2) toe-width and (3) Tennant (aka 'Montana') method [3]. In keeping with the format adopted by the Washington Department of Ecology, the IFIM technique was used in this study. Computational routines for assessing the appropriate level of instream flow requirements have been developed and used based on the IFIM [4], although close analysis of input and interpretation of output results is still more art than science. The simplicity of the weighted usable area (WUA) curves generated by the Physical HABitat Simulation (PHABSIM) model can 
be deceptive in terms of identifying appropriate flows across the various life stages of each species. A number of studies have critically examined the WUA process with most reaching the conclusion that the nature of the relationship between fish and WUA may be unique for each stream [5]. Furthermore, a considerable amount of uncertainty exists in the preference factors assigned to the various life stages of bull trout and salmonid species. Much of this stems from the processes traditionally used to determine factors related to juvenile rearing, spawning and migration. Preference factors developed for larger rivers are sometimes inappropriately used for smaller stream prevalent in arid and semi-arid regions.

This study used the Touchet River Basin in Southeastern Washington, USA, as the basis for evaluating the hypothesis that understanding uncertainty and variability in the PHABSIM preference curves will result in improved decision-making capabilities. We used an earlier IFIM study by Barber et al. [6] as the starting point for the initial calibrated modelling effort. The original study of instream flow requirements was conducted for Columbia Conservation District in Dayton, Washington, USA, as part of an effort to protect and restore salmonid species in the Touchet River watershed. Modifications to the preference factors were used to demonstrate the impacts of uncertainty on the results.

\section{BACKGROUND}

The Touchet River watershed (Fig. 1) is a tributary to the Walla Walla River, which contains several cold water stream reaches that are important to anadromous and endangered fish species. The most valuable fish habitat consists of approximately $425 \mathrm{~km}^{2}\left(163 \mathrm{mi}^{2}\right)$ upstream of the Patit Creek confluence [7]. The PHABSIM computer model developed by the United States Geological Survey was used in this investigation [8]. PHABSIM is intended to simulate streamflow and physical habitat relationships for various life stages or recreational activities and is commonly used to calculate the WUA for each cross section over a range of flows. The WUA is computed sequentially using three distinct model subroutines (WSL, velocity and Habtae) and an equation in the form of

$$
\mathrm{WUA}=\sum_{i=1}^{N} A_{i} \times\left(\mathrm{PF}_{\mathrm{d}} \mathrm{PF}_{\mathrm{v}} \mathrm{PF}_{\mathrm{s}} \mathrm{PF}_{\mathrm{c}}\right)_{i}
$$

where $A$ is the cell area, $\mathrm{PF}_{\mathrm{d}}$ is a depth preference or weighting factor, $\mathrm{PF}_{\mathrm{v}}$ is a velocity preference factor, $\mathrm{PF}_{\mathrm{s}}$ is a substrate preference factor, $\mathrm{PF}_{\mathrm{c}}$ is a cover preference factor and $N$ is the number of cells in the cross section.

WSL is the routine used to predict water surface elevations at cross sections based on field data and the total energy as a channel section based on the open channel form of Bernoulli's equation. Velocity is the model that simulates velocity profiles using an empirical approach and an assumption that each cross section can be treated independently. Habtae is the main model that compiles results from WSL, velocity and preference factors into the WUA predictions [8].

Preference factors involve the important aspects of all fish life stages; substrate, cover, water depth and water velocity. Table 1 summarizes the substrate preferences for important fish species in the Touchet River watershed as a function of life stage. Table 2 expresses the values for cover. This information is collected during field investigations at the same time velocity and depth characteristics are being compiled. As indicated in eqn (1), these factors are multiplied together without regard to any special weighting, thus making all factors equally important. 


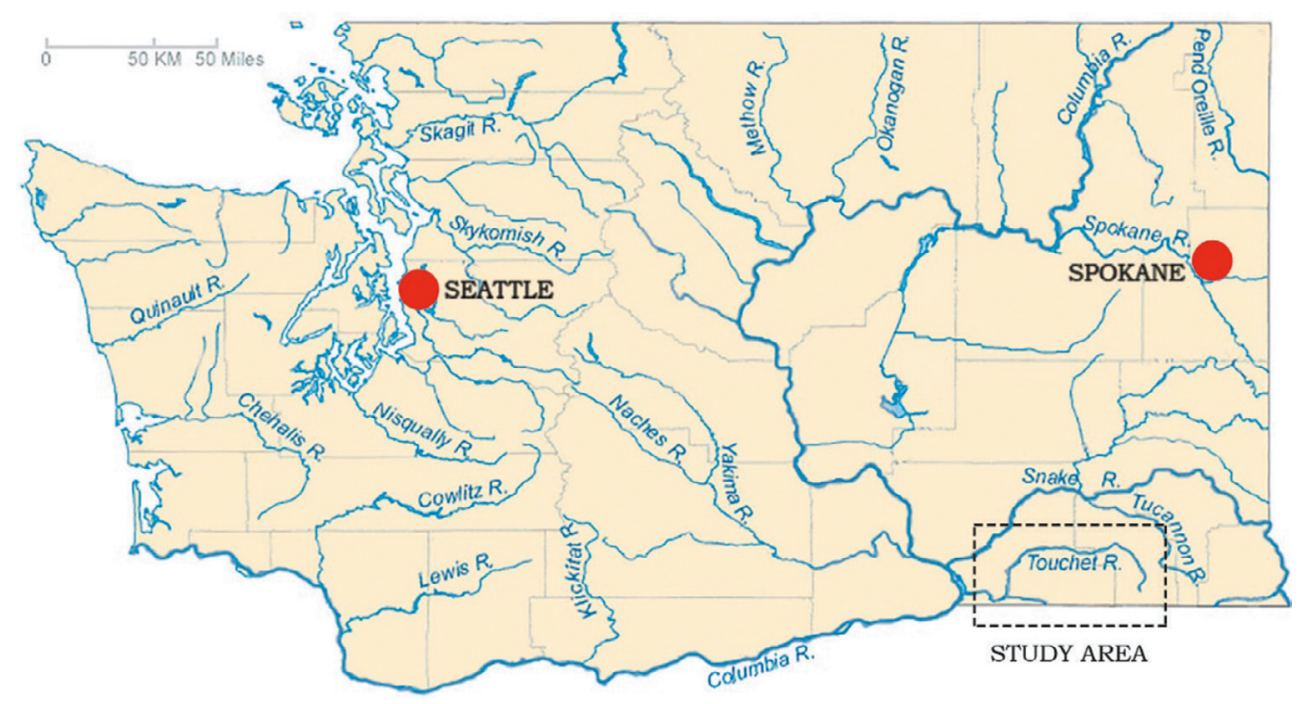

Figure 1: Touchet River Basin in Southeastern Washington State, USA.

Table 1: Substrate preference values [9].

\begin{tabular}{|c|c|c|c|c|c|c|c|c|}
\hline \multirow[t]{2}{*}{ Code } & \multirow[t]{2}{*}{ Substrate } & \multicolumn{4}{|c|}{ Spawning } & \multicolumn{2}{|c|}{ Rearing } & \multirow{2}{*}{$\frac{\text { Holding }}{\text { Adult }}$} \\
\hline & & Salmon & Steelhead & Trout & Bull trout & Fry & Juvenile & \\
\hline 1 & Silt, clay & 0.0 & 0.0 & 0.0 & 0.0 & 0.1 & 0.1 & 0.1 \\
\hline 2 & Sand & 0.0 & 0.0 & 0.0 & 0.0 & 0.1 & 0.1 & 0.1 \\
\hline 3 & $\begin{array}{l}\text { Small gravel } \\
(0.25-1.25 \mathrm{~cm})\end{array}$ & 0.3 & 0.5 & 0.5 & 1.0 & 0.1 & 0.1 & 0.1 \\
\hline 4 & $\begin{array}{l}\text { Medium gravel } \\
(1.25-3.8 \mathrm{~cm})\end{array}$ & 1.0 & 1.0 & 1.0 & 1.0 & 1.0 & 0.3 & 0.3 \\
\hline 5 & $\begin{array}{l}\text { Large gravel } \\
(3.8-7.6 \mathrm{~cm})\end{array}$ & 1.0 & 1.0 & 1.0 & 1.0 & 1.0 & 0.3 & 0.3 \\
\hline 6 & $\begin{array}{l}\text { Small cobble } \\
(7.6-15.2 \mathrm{~cm})\end{array}$ & 1.0 & 1.0 & 1.0 & 0.7 & 1.0 & 0.5 & 0.3 \\
\hline 7 & $\begin{array}{l}\text { Large cobble } \\
(15.2-30 \mathrm{~cm})\end{array}$ & 0.5 & 0.3 & 0.3 & 0.7 & 1.0 & 0.7 & 0.3 \\
\hline 8 & Boulders $(>30 \mathrm{~cm})$ & 0.0 & 0.0 & 0.0 & 0.0 & 1.0 & 1.0 & 1.0 \\
\hline 9 & Bedrock & 0.0 & 0.0 & 0.0 & 0.0 & 0.1 & 0.3 & 0.3 \\
\hline
\end{tabular}

Spawning preference curves (depth and velocity curves) have been developed for two types of waterways: (1) large rivers and (2) streams and rivers. The dividing line between types 1 and 2 is a mean annual flow of $28.3 \mathrm{~m}^{3} / \mathrm{s}\left(1,000 \mathrm{ft}^{3} / \mathrm{s}\right)$. However, this divide is somewhat subjective and arguably not appropriate for streams and rivers in arid and semi-arid environments where mean flows are much lower and even peak flows may not reach the threshold. When they exist, preference factors developed for smaller streams are based on a small sample size 
Table 2: Cover preference values [9].

\begin{tabular}{lcccc}
\hline Cover type & \multicolumn{2}{c}{ Rearing } & & Holding \\
\cline { 2 - 3 } \cline { 5 - 5 } \cline { 5 - 5 } & Fry & Juvenile & & Adult \\
\hline Undercut bank & 1.0 & 1.0 & \\
Overhanging vegetation & 1.0 & 1.0 & & 1.0 \\
Root wad & 1.0 & 1.0 & \\
Log jam/submerged brush pile & 1.0 & 1.0 & & 1.0 \\
Log(s) parallel to bank & 0.3 & 0.8 & \\
Aquatic vegetation & 1.0 & 0.8 & \\
Short $(<30$ cm) terrestrial grass & 0.4 & 0.1 & \\
Tall $(>90 \mathrm{~cm})$ terrestrial grass & 0.7 & 0.8 & 0.1 \\
Vegetation beyond the bank-full water edge & 0.2 & 0.2 & & 0.1 \\
\hline
\end{tabular}

or other similar streams which are contrary to studies indicating unique stream characteristics [5]. Rearing preference is considerably more subjective, while spawning preference is relatively straightforward because depths and velocities can be measured at redds (salmon/ steelhead spawning beds); rearing surveys are based on visual observations where a fish is spotted, which may be a preference or random.

For example, based on data collected at 25 redds, Figs 2 and 3 illustrate the spawning depth and velocity preference factors for steelhead. In each case, the measured values are shown in dashed lines, whereas the recommended values are shown in blue.

The variability between calculated and observed, which is clearly visible in the adult steelhead curves, is also present in the juvenile depth and velocity preference factors. Similarly, preference curves for salmon species (chinook, coho and sockeye) as well as bull and cutthroat trout demonstrate inherent variability that can have significant impact on interpretation of the results if users are not careful.

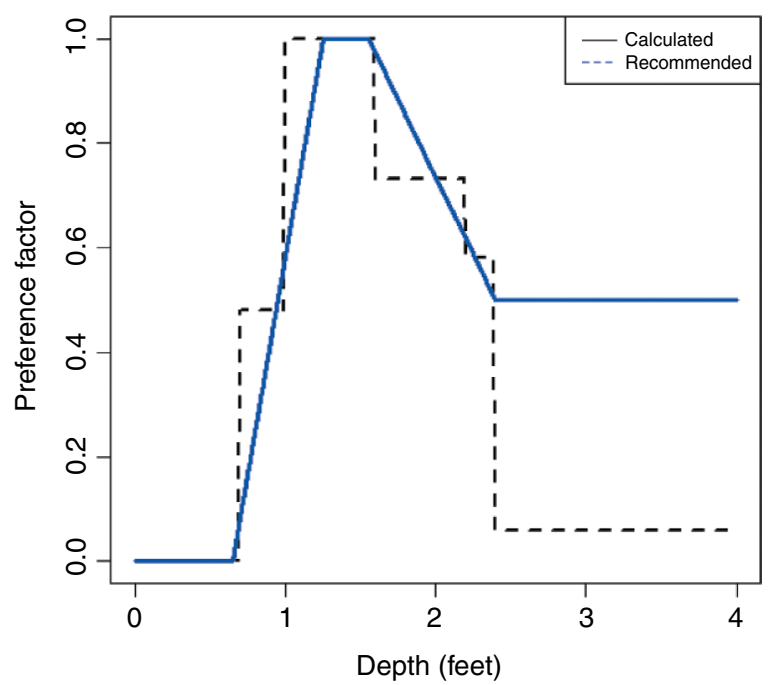

Figure 2: Steelhead depth preference factors [9]. 


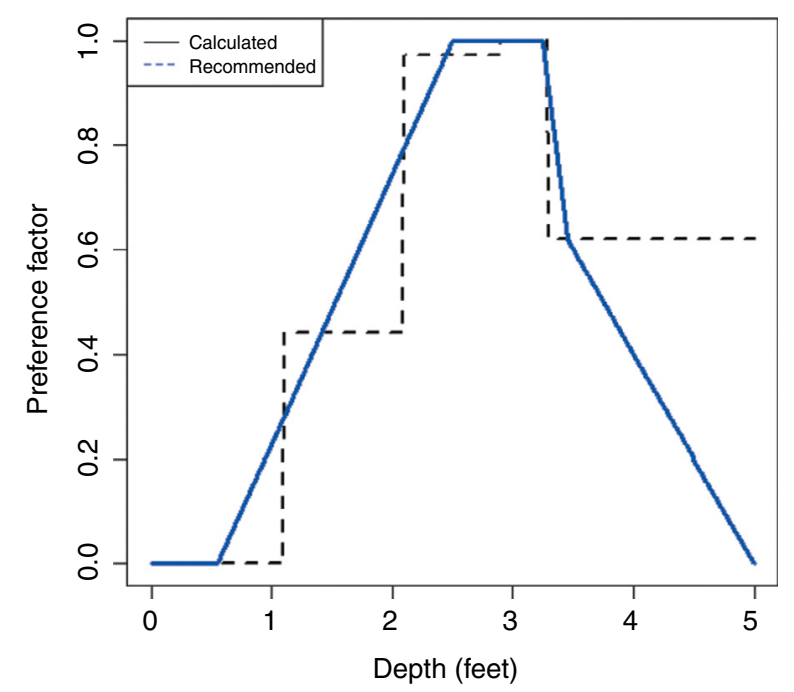

Figure 3: Steelhead velocity preference factor [9].

\section{METHODOLOGY}

The amount of water needed to protect aquatic fish species is determined by considering existing data, the hydrology of a stream and its natural variations in flow over the year, fish requirements and other related factors. Several procedures are available for determining minimum flow requirements, ranging from standard-setting techniques to incremental techniques. IFIM was originally developed by the U.S. Fish and Wildlife Service [10], primarily as a means of determining flow requirements downstream of hydropower relicensing efforts. The methodology integrated water supply requirements with analytical models from hydraulic and water quality engineering and empirically derived habitat versus flow functions. Over a period of 15 years, IFIM has developed into a river network analysis that incorporates fish habitat, recreational opportunity and woody vegetation response to alternative water management schemes [3].

There are five critical steps to conduct an IFIM analysis:

1) Problem identification

2) Study planning

3) Study implementation

4) Alternative analysis

5) Problem resolution

These steps interact to form the basis for the watershed plan. In this article, we focus on steps 1, 2 and 3 as impetus for the follow-on activities. Using the PHABSIM for Windows Version 1.5.1 model and the procedure and preference curves previously discussed, WUA curves were developed for steelhead and bull trout on three segments: Touchet River, North Fork Touchet River and Wolf Fork Creek. A screenshot of the Habtae user interface showing the range of options associated with WUA calculations is shown in Fig. 4. Clicking the Run button (after calibrating the WSL and velocity routines) generates files and graphs of WUA. 


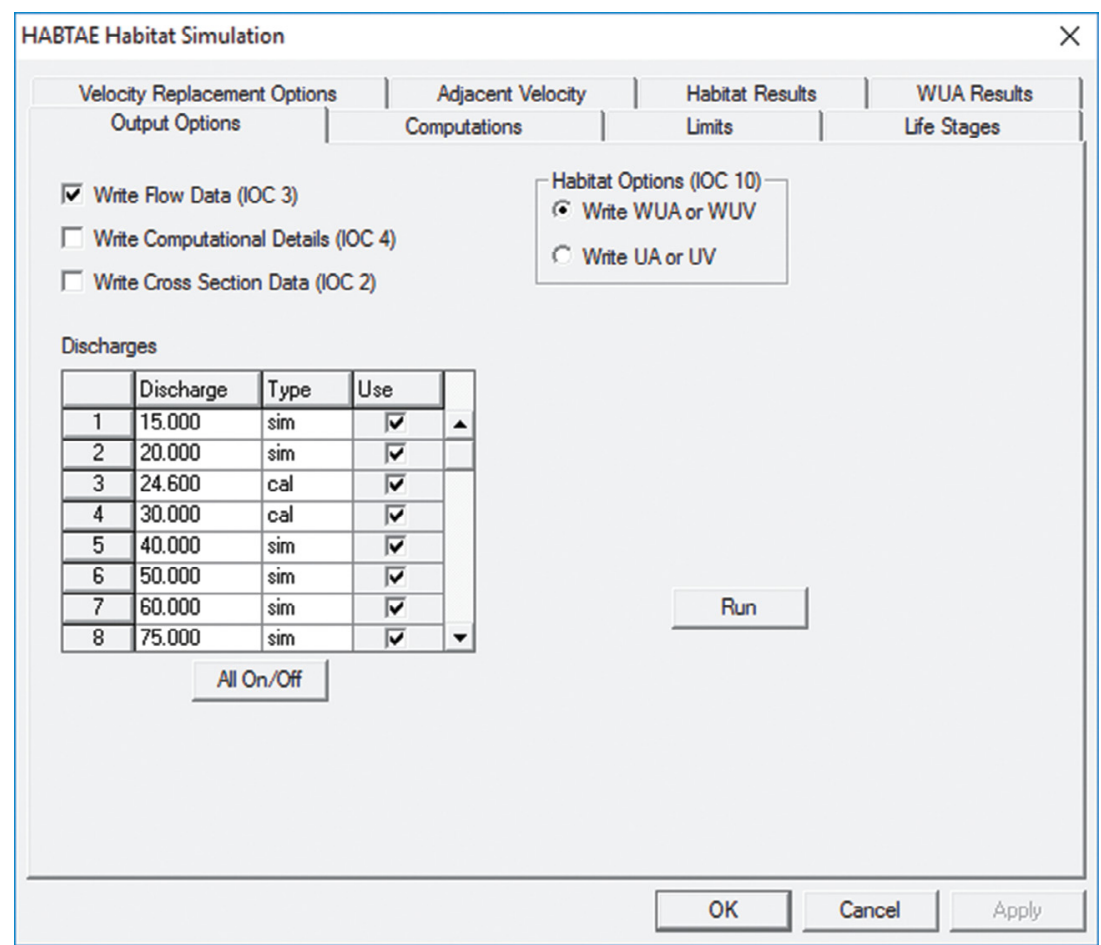

Figure 4: HABTAE user interface for calculating weighted usable area (WUA).

Because the variability in results is linear to the preference factors (eqn (1)), there was no need to run additional simulations to evaluate uncertainty. This was done using Excel and by performing sensitivity analysis of WUA values.

\section{RESULTS AND DISCUSSION}

WUA values were generated for various life stages of anadromous and resident fish populations threatened or endangered in the Pacific Northwestern USA. Tables 3 and 4 present the WUA values for steelhead and bull trout on the Wolf Fork Creek tributary. By themselves, these values are difficult to interpret. Information regarding existing stream flows, fish use throughout the year and options for mitigating shortages must be considered. Furthermore, determining which is the critical life stage is difficult to do with variable hydrologic conditions and the impacts of harvest, hatcheries, hydropower and downstream habitat factors. The three submodels (WSL, velocity and Habtae) generate copious amounts of data that is important to carefully examine in order to understand and interpret results. Space limitations that dictate only brief summaries can be presented here. More information can be found in the original technical report prepared for the Conservation District [6].

It is considerably easier to understand the meaning of these values by using the graphing function of PHABSIM. Figures 5 and 6 illustrate WUA as functions of flow for steelhead and bull trout on the Wolf Fork Creek tributary. Similar graphs were generated for the other streams in the study area. 
Table 3: WUA values for steelhead on Wolf Fork Creek.

\begin{tabular}{lrrr}
\hline Discharge $\left(\mathrm{m}^{3} / \mathrm{s}\right)$ & Spawning & \multicolumn{1}{c}{ Fry } & Juvenile \\
\hline 0.43 & 635.5 & $5,210.0$ & 787.8 \\
0.57 & $1,279.4$ & $4,598.9$ & 962.2 \\
0.70 & $2,027.1$ & $4,416.4$ & $1,103.0$ \\
0.85 & $2,950.2$ & $4,377.7$ & $1,241.9$ \\
1.13 & $4,731.0$ & $3,703.6$ & $1,454.1$ \\
1.42 & $6,330.8$ & $2,728.9$ & $1,622.8$ \\
1.70 & $7,530.0$ & $2,302.3$ & $1,683.8$ \\
2.13 & $9,240.9$ & $1,837.2$ & $1,674.8$ \\
2.55 & $10,463.2$ & $1,504.2$ & $1,669.3$ \\
2.89 & $10,571.6$ & $1,100.9$ & $1,669.2$ \\
3.12 & $10,693.7$ & 933.4 & $1,673.7$ \\
3.54 & $10,611.4$ & 986.9 & $1,652.9$ \\
3.97 & $10,455.5$ & $1,195.6$ & $1,614.3$ \\
4.25 & $10,037.5$ & $1,331.4$ & $1,593.7$ \\
\hline
\end{tabular}

Table 4: WUA values for steelhead on Wolf Fork Creek.

\begin{tabular}{lrl}
\hline Discharge $\left(\mathrm{m}^{3} / \mathrm{s}\right)$ & Spawning & Adult \\
\hline 0.43 & $8,667.1$ & $2,082.1$ \\
0.57 & $9,649.3$ & $2,431.2$ \\
0.70 & $10,162.7$ & $2,810.9$ \\
0.85 & $10,594.9$ & $3,300.4$ \\
1.13 & $11,122.7$ & $4,306.8$ \\
1.42 & $11,395.3$ & $4,911.3$ \\
1.70 & $11,524.0$ & $5,435.2$ \\
2.13 & $11,290.7$ & $5,687.8$ \\
2.55 & $10,930.7$ & $6,025.9$ \\
2.89 & $10,678.7$ & $6,023.0$ \\
3.12 & $10,539.6$ & $6,023.9$ \\
3.54 & $10,260.6$ & $5,707.2$ \\
3.97 & $9,804.1$ & $5,277.6$ \\
4.25 & $9,412.3$ & $4,955.2$ \\
\hline
\end{tabular}

Although easier to understand, interpretation for the purposes of establishing instream flow requirements is challenging. Steelhead spawning peaks are above $2.8 \mathrm{~m}^{3} / \mathrm{s}\left(100 \mathrm{ft}^{3} / \mathrm{s}\right)$ while bull trout spawning peaks are close to $1.7 \mathrm{~m}^{3} / \mathrm{s}\left(60 \mathrm{ft}^{3} / \mathrm{s}\right)$. Determining which species should be preferred even if they use the stream at the same time of the year is difficult. The low adult curve for bull trout indicates the adults may actually prefer to migrate elsewhere in the watershed so perhaps their needs could be considered not as important. Furthermore, other life stages peak at considerably different values. However, it is also important to realize the impact of even minor changes in the preference curves on interpretation of results. For example, instead of multiplying depth and velocity preferences of $0.7 \times 0.7=0.49$, using values 


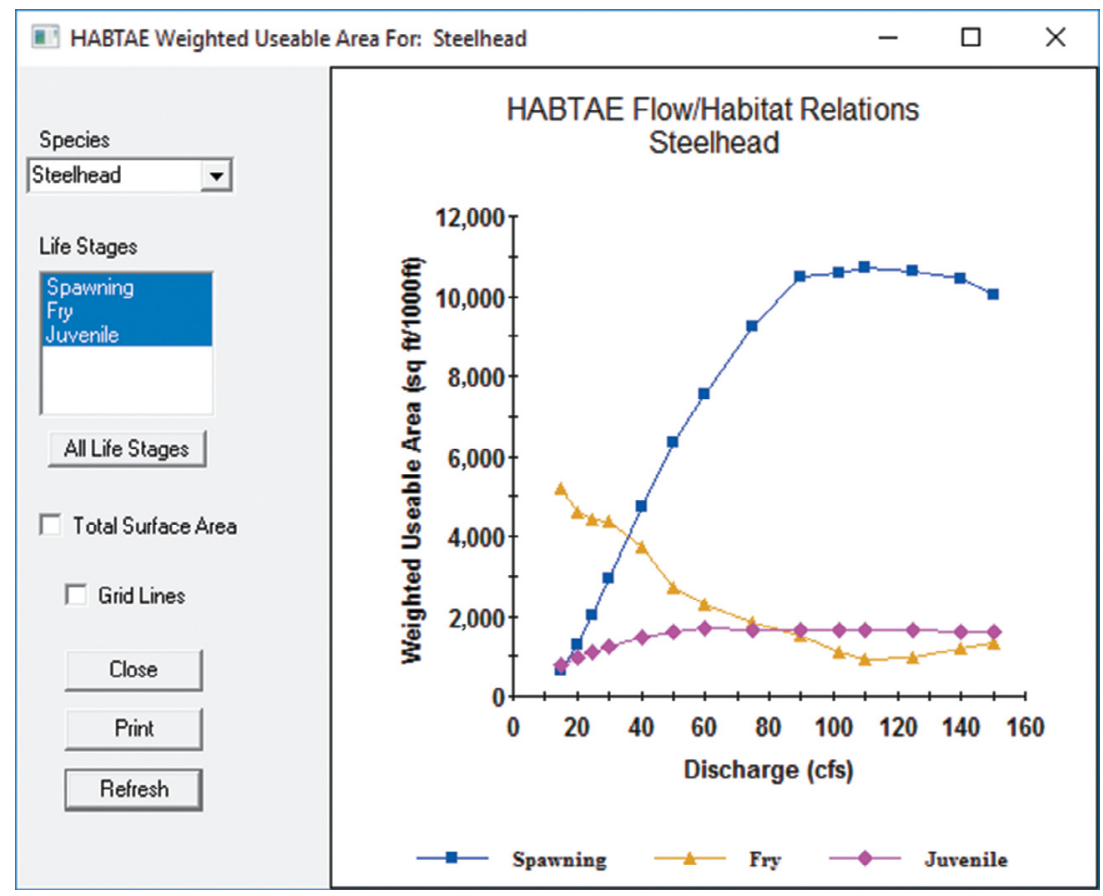

Figure 5: WUA for all life stages of steelhead on Wolf Fork Creek.

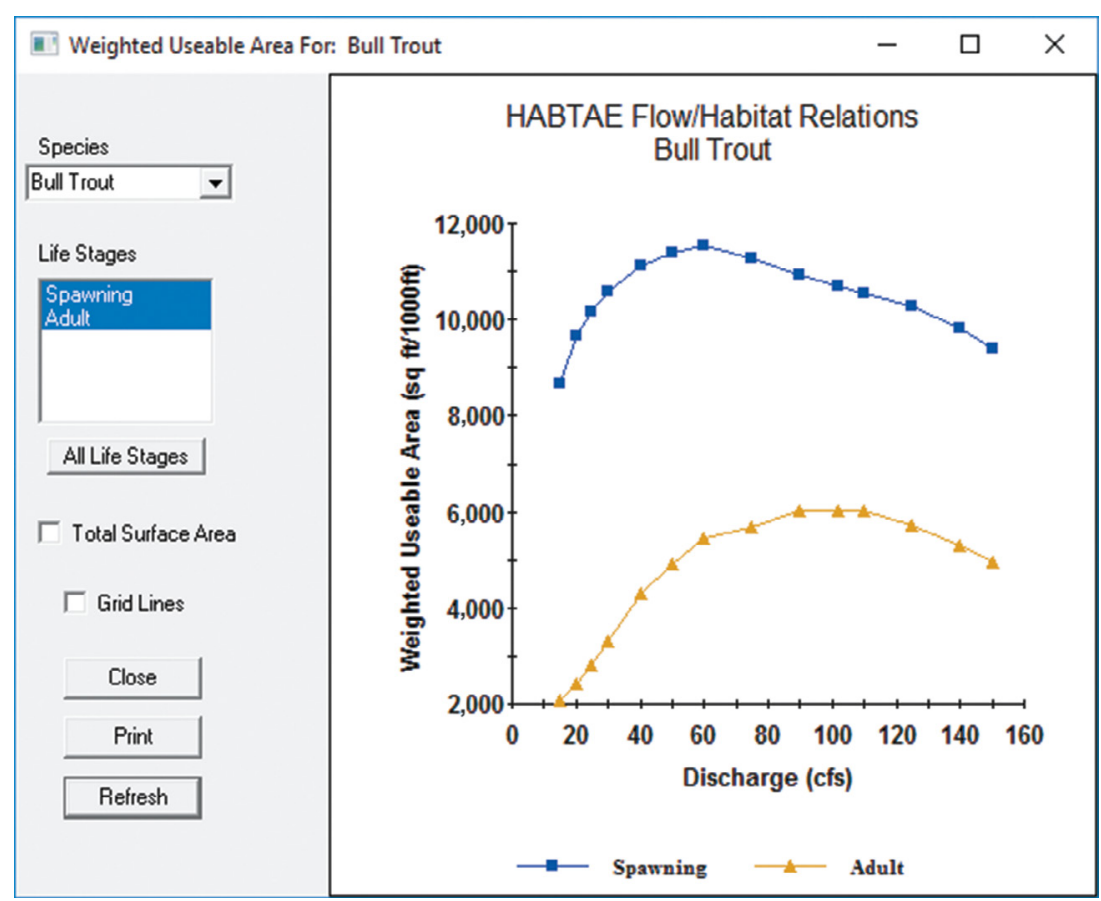

Figure 6: WUA for all life stages of bull trout on Wolf Fork Creek. 


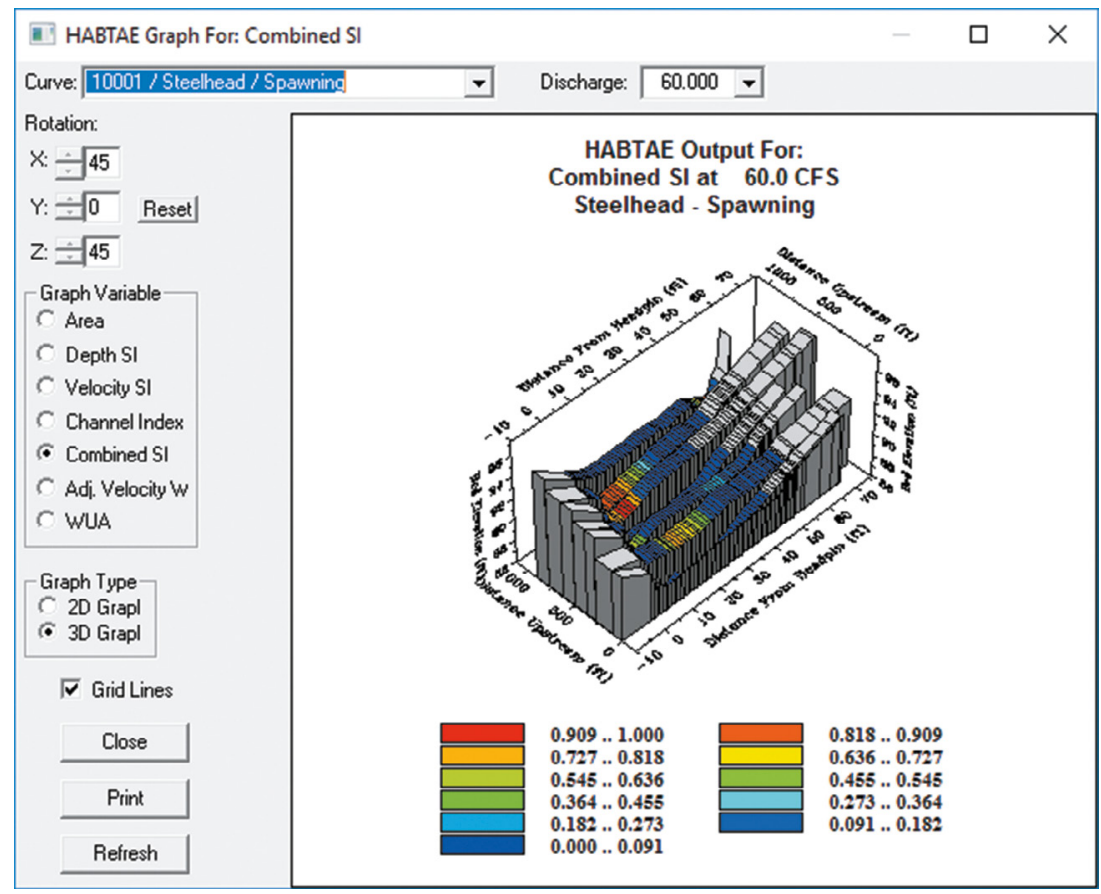

Figure 7: Location of steelhead spawning at $1.7 \mathrm{~m}^{3} / \mathrm{s}\left(60 \mathrm{ft}^{3} / \mathrm{s}\right)$ on the Touchet River.

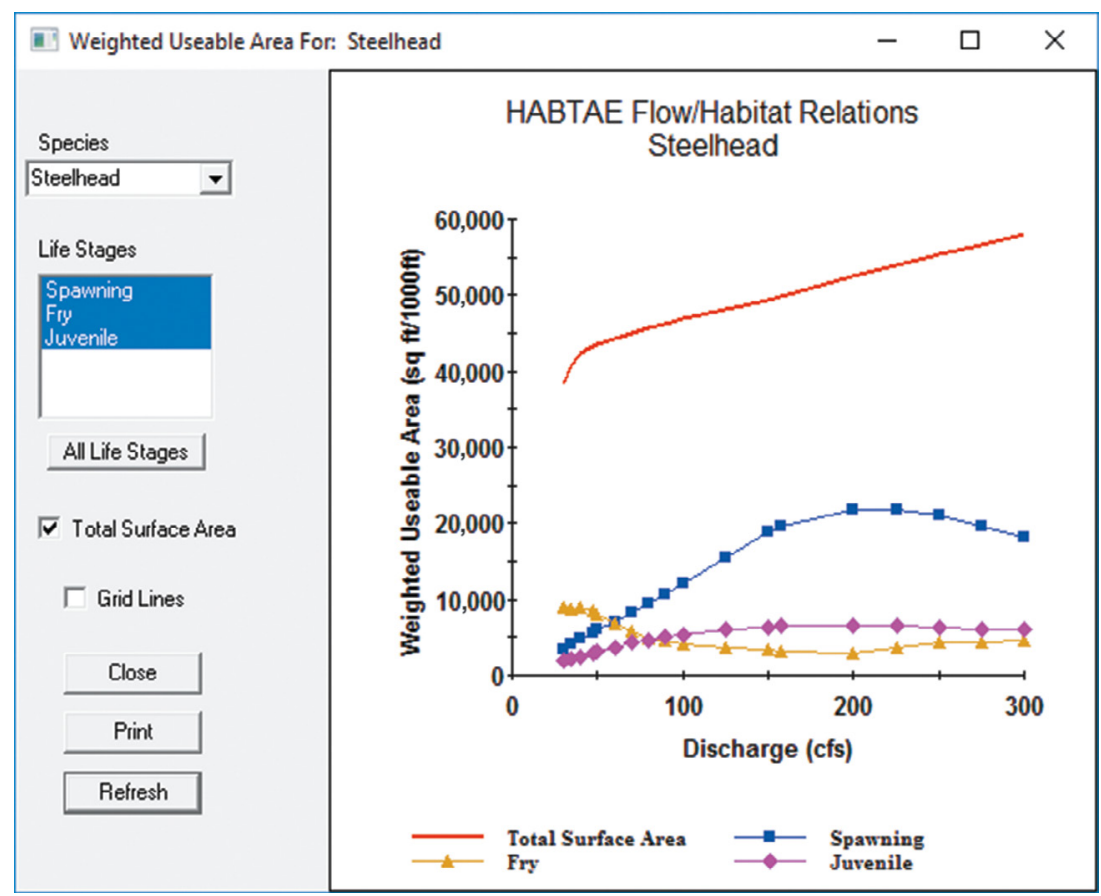

Figure 8: WUA with respect to total stream area for Touchet River Steelhead. 
that vary by $10 \%$ (e.g., 0.63 ) reduces WUA by $20 \%$. Compounding cover and substrate factors further complicates the analysis.

Figure 7 illustrates another feature of the PHABSIM model by allowing users to see where the high value habitat is within the study area. Connectivity of habitat is essential to healthy fish populations so habitat restoration activities should consider this during the planning phase.

To understand the options for improving stream habitat, PHABSIM can produce results in relationship to total stream surface area. Figure 8 illustrates the usable area compared to total area for steelhead in the Touchet River. As shown, fish are able to use between 10\% and 50\% of the total area. While an analysis of what could be done to improve these values was outside the scope of this work, it is very useful for comparison purposes and prioritizing restoration efforts.

\section{CONCLUSIONS AND RECOMMENDATIONS}

Preference curves developed for wet regions may not be applicable to semi-arid river basins, where stream flows are often quite small in comparison. The range of flows shown in our analysis are typically far below the threshold dividing large and small rivers and streams. The sensitivity of moving the WUA curves up or down with small variations in flow indicates the importance of establishing local preference curves. While this will be a time-consuming and expensive undertaking, the consequences of failure could be extinction of species or overprotection at high costs to residents of the watershed.

\section{REFERENCES}

[1] Richter, B., Mathews, R., Harrison, D. \& Wigington, R., Ecologically sustainable water management: Managing river flows for ecological integrity. Ecological Applications, 13(1), pp. 206-224, 2003. DOI: 10.2307/1938620.

[2] Falkenmark, M. \& Molden, D., Wake up to realities of river basin closure. International Journal of Water Resources Development, 24(2), pp. 201-215, 2008. DOI: 10.1080/07900620701723570.

[3] Rushton, C.D., Instream Flows in Washington State: Past, Present and Future, Washington Department of Ecology: Olympia, WA, 2000.

[4] Stalnaker, C., Lamb, B., Henriksen, J., Bovee, K. \& Bartholow, J., The Instream Flow Incremental Methodology: A Primer for IFIM, Biological Report 29, U.S. Department of the Interior: Washington, DC, 1995.

[5] Conder, A.L. \& Annear, T.C., Test of weighted usable area estimates derived from a PHABSIM model for instream flow studies on trout streams. North American Journal of Fisheries Management, 7, pp. 339-350, 1987. DOI: 10.1577/1548-8659(1987)7\&1t; 339:TOWUAE\&gt;2.0.CO;2.

[6] Barber, M., Juul, S., Saul, D., Cichosz, T. \& Rabe, C., Instream Flow Incremental Methodology Analysis and Streamflow Data Collection of the Touchet River System Within Columbia County. Technical Report, Columbia Conservation District, Dayton, WA, 2001.

[7] GeoEngineers, Geomorphic Assessment, Touchet River Upstream of Dayton, Washington, GeoEngineers: Spokane, WA. 2011.

[8] Milhous, R.T. \& Waddle, T.J., Physical Habitat Simulation (PHABSIM) Software for Windows (v.1.5.1), USGS Fort Collins Science Center: Fort Collins, CO, 2012. 
[9] Beecher, H., Vada, B., Caldwell, B., Pacheco, J. \& Marti, J., Instream Flow Study Guidelines: Technical and Habitat Suitability Issues, Washington Department of Fish and Wildlife: Olympia, WA, 2008.

[10] Trihey,E.W. \& Stalnaker, C.B.,Evolution and application of instream flow methodologies to small hydropower development: An overview of the issues. Proceedings of the Symposium on Small Hydropower and Fisheries, eds. F.W. Olson, R.G. White \& H. Hamre, The American Fisheries Society: Denver, CO, 1985. 